\title{
A critical analysis of Gretha Wiid's sex ideology and her biblical hermeneutics
}

\begin{abstract}
Author:
Lilly Nortjé-Meyer ${ }^{1}$

Affiliation:

${ }^{1}$ Department of Religion

Studies, University of

Johannesburg, South Africa

Correspondence to:

Lilly Nortjé-Meyer

Email:

lillynm@uj.ac.za

Postal address:

PO Box 524, Auckland Park

2006, South Africa

Dates:

Received: 15 Oct. 2010

Accepted: 08 Sept. 2011

Published: 28 Nov. 2011

How to cite this article: Nortjé-Meyer, L., 2011, 'A critical analysis of Gretha Wiid's sex ideology and her biblical hermeneutics', Verbum et Ecclesia 32(1), Art. \#472, 7 pages. http://dx.doi. org/10.4102/ve.v32i1.472
\end{abstract}

(C) 2011. The Authors. Licensee: AOSIS OpenJournals. This work is licensed under the Creative Commons Attribution License.
Gretha Wiid and Angus Buchan have established themselves as the moral gurus of the Afrikaner Christian community with their 'Worthy Women' and 'Mighty Men' mass conferences. Wiid is also often invited by the broadcast media to participate in TV and radio talks to discuss her views on relationships and sex - she is even invited by popular Afrikaans singers to share the stage with them. Recently, Gretha Wiid was again on the front pages of popular magazines to promote her and her husband's views on sex and sexuality based 'on the Bible'. She suggests that women hand over their sexuality, their bodies and their sexual decisions completely into the hands of men. Her view is that the husband is the king, prophet and priest in the family and should be honoured accordingly. The aim of this article was to use Wiid's public appearances and publications as a case study to analyse her statements, hermeneutic principles and procedures and to demonstrate how her interpretation of sex and sexuality is infused by heteropatriarchal biblical discourse. The purpose of the article was to unveil the hermeneutic principles 'ordinary' Christians such as Wiid apply in interpreting biblical texts and how these are culturally inscribed on women's and children's bodies.

\section{Preliminary general considerations}

Owing to the emotionally charged nature of the topic of this paper, it seems justifiable to begin by stating my general frame of reference. Firstly, I approach the topic from a gender critical point of view. That implies that I consider the material under discussion through a specific critical lens - the approach of the hermeneutics of suspicion (cf. Schüssler-Fiorenza 2001:176) - in order to problematise patriarchy and heteronormativity (cf. Jackson 2003). Secondly, approaching the topic from this perspective implies adopting a specific chosen ideology and not assuming a neutral position, as gender criticism insists. As such, I write in the first person. Thirdly, I choose this topic and mode of presentation because I aim to broaden the parameters within which academic research is defined. In the formulation of a new production of knowledge, an uneasiness regarding traditional parameters for academic research has been discussed by researchers such as Michael Gibbons et al. (1994) and William Starbuck (2006). When considering how the production of gender knowledge is affected, Mikaelsson (2008:300) highlights the power relationships within the academy, 'like the power of established scholars to define what are the interesting topics and established standards of good research'. Therefore, the topic of gender research within its religious context should also focus on women's lives, experiences, their contributions to art, literature, culture and society, as illustrated by the article entitled 'Gender representation in Christian book covers: A case study' that was recently published by Stella Viljoen and Leandra Koenig-Visagie (2011).

\section{Introduction}

Biblical discourse plays a constitutive role in the gendered coding of culture. Gretha Wiid has availed herself of biblical material in the establishment of gender relations and identification in the South African culture. In this article, her public appearances, as recorded on her official DVDs (Wiid 2009c, 2009d, 2009e) and her publications (Wiid 2009a, 2009b) are studied to demonstrate how women, and especially the female body, are inscribed by patriarchal culture through heteronormative readings of biblical discourse and formenism. ${ }^{1}$ Furthermore, Wiid's public discourse and her youth literature echo ideologies supportive of supremacy, or heteropatriarchy as institutional power and are backed with religious control (cf. Hawthorne 2007:2). Therefore, she motivates her statements through biblical discourse and the aim of this article is to analyse the hermeneutical principles and procedures Wiid applies to support her statements and how she promotes heteropatriarchal ideology in the process.

Heteronormativity can be defined as heterosexuality and heterosexual relationships that are perceived and presented by society as the only 'natural, healthy, universally socially and morally

1.'Formenism' is sustained by women for, or on behalf of, men and, as with masculinism, subscribes to the inherent superiority of men over women (cf. Nadar \& Potgieter 2010:141ff.) A discussion of these concepts will follow later. 
acceptable expressions of adult sexuality' (Dunne 2003:60). Questioning heteronormativity means to problematise heterosexuality as an institution and as an identity as it is practised and experienced and to question, destabilise, disturb and trouble the normative status of heterosexuality (cf. Nortjé-Meyer 2010:143). Furthermore, a critique of heteronormativity in terms of social structures contains two key elements:

It is a critique of the normative status of heterosexuals, which renders alternative sexualities as 'other' and 'marginal'. And, it is also a critique of what can be called 'hetero-patriarchy' or 'hetero-oppression'. That refers to a system of systematic male dominance. A critique of heteropatriarchy should then pay attention to its use of gender in terms of its divisions and hierarchy. Compulsory heterosexuality and therefore patriarchy keeps women in (within its gender and sexual confines) and down, namely subordinate.

(Nortje-Meyer 2010:144)

Institutionalised heteropatriarchy and heteronormativity as social totalities refer to the systematic and systemic power and control men have over women. Therefore, men as a group and as individuals oppress women as a group and as individuals. This means that men's power over women functions hierarchically and is not merely a matter of men and women having different measures of power, making them unequal in the system. Men's power lies in every single relation between men and women, rather than being defined primarily by their role in state apparatuses, or by their ownership of the means of production. It is important to notice that men's violence against women is also not an isolated phenomenon but is part of the structural violence that men as a group use against women as a group. In a heteropatriarchal society, all men have power over all women, regardless of whether they choose to exercise that power or not. Therefore, it is not only that men treat women badly - although often they do - but that it is their choice whether or not to do so. But because men are not isolated from the patriarchal society at large, they always have this socially and culturally supported power and can always choose to use it or not. Even if men choose not to exercise power over women, all women are exposed to violence: all women are continuously aware of the existence of this power against them and are affected by it. In this way, all acts of violence against women are beneficial to all men and strengthen their power over all women (cf. People's Global Action Conference 2008).

Most ideologies of oppression work in the same way, in that they create two different categories or binaries and then assign certain traits to one group over and against the other. In doing so, this ideology places a higher value on the individuals belonging to one group, whilst deeming everyone else to possess traits that are inferior. Such a value system ranks 'male' higher than 'female' and is often complicit in ranking Whites above non-Whites, the upper class above the working class, adults above children, humans above animals, and so on (cf. Jackson 2003:70-71). Wiid's whole debate is based on the binary category that a man is valued higher than a woman. Although Wiid declares clearly that the husband is not the 'boss' of the wife, she maintains that he is the head of the wife, as Christ is the head of the Christian community (cf. Eph 5:23-24), and therefore has supremacy over the wife. Buchan echoes the same hierarchy between men and women, but also values Enlightened European belief higher than Dark African non-belief (cf. Buchan, Greenough \& Waldeck 2006:158). What follows is an analysis of Wiid's hermeneutical principles and procedures and the way she applies these principles to biblical discourse to support her statements, as well as how she promotes the inherent superiority of men over women, therefore promoting 'formenism' and heteropatriarchal ideology in the process.

\section{Wiid's rationale for her public appearances}

When I started reading through Wiid's literature on sex, written for boys and parents of teenagers, and watching the DVDs of her 'Worthy Women' conference in 2008 and her documentaries, 'Seks in die huwelik - Jou lus, las of liefde?' [Marital sex - Your lust, burden or love?] and 'Verstaan jou man beter: Finessekenner' [Understand your husband better: Finesse expert], I really regretted my topic. It took me much longer to read through this simple Afrikaans teenage literature than I had bargained for - not because of the complexity of the language or argumentation, but mainly because of my frustration with the content and its theological and ideological grounding.

Although Wiid and her husband Francois are marriage consultants, she is not qualified as a minister, marriage or sex therapist, advisor or consultant. She actually describes herself as a 'finessekenner', or finesse expert - whatever this might be (2009e). She earns her money from holding conferences and especially school talks and camps on sex counselling. During an interview with Freek Robinson on his radio programme Praat Saam [Talking Together] on RSG (09 September 2009), with Prof. Hansie Wolmarans, Gretha Wiid and myself as guests, she claimed to have several MA degrees, ${ }^{2}$ but during an earlier interview with Elmari Craig, a qualified sexologist (Craig \& Stander 2009), Wiid admitted that she has no professional qualification (cf. Swart-Walters 2010b:18-19). She claims that her sources of information are 'informed people', reading the Bible and what Jesus and God tell her. She claims she is on a god-sent mission and does not speak in her own right, but through the power of the Holy Spirit (2009c). ${ }^{3}$

Wiid and Buchan's conferences were completely independently organised and presented. But, she says that she had visited Buchan before her conference to make sure their visions corresponded one hundred percent (cf. Jackson 2009). The 'vision' they share is to restore 'order' in South Africa and this can only be done, they believe, if order in the

2.In this she was probably referring to her status as the mother of four children (in Afrikaans, the letters ' $M$ ' ' $A$ ' spell ' $m a^{\prime}$ ', which means 'mother'). For, if Wiid does indeed hold these postgraduate qualifications, she has yet to provide proof of them.

3.The same claim is made by the apostle Paul in 1 Corinthians 7:10, 12, 40. 
family is restored. This restoration of family order can, in turn, only take place when the man, as husband, father and master, takes back his rightful place as the head of the family and as the representative of Christ (cf. Buchan et al. 2006:167). It seems that the desire to restore order in the country stems from the insecurity of White people caused by high levels of crime (especially violent crime) and the general immorality that is reflected by mismanagement, corruption and the spread of HIV and AIDS. A good example is Buchan's view that Africa is still the 'Dark Continent' (cf. Buchan et al. 2006:158). A subtext in their discourse is definitely the problem they have with the liberation movements, whether defined by politics or gender, and the fact that Afrikaner nationalism has not disappeared (Nadar 2009b:7). Wiid (2009c) says, for example, that 'if we come to terms with the order" in the household, our marriages will be blessed.' It is not about 'who has the last word in an argument' or whether 'we have to burn our bras' to restore order, she says (Wiid 2009c; cf. also Nadar \& Potgieter 2010:147). Therefore it seems that Buchan and Wiid blame the disorder in the country indirectly on the liberation of women and, accordingly, their positions in private and public spaces. Their ideology reflects masculinism (Nadar 2009b:2-3) and formenism (Nadar \& Potgieter 2010:143ff), biblically founded beliefs in the inherent superiority of men over women.

As a result of her and her husband's extra-marital affairs and use of pornography in the past, Wiid focuses especially on the sexual relationship between husband and wife (Wiid 2009c). In addressing sexual relationships, she does not refer to or define sex as recreational. Nor does she acknowledge any other important sex-related issues such as infertility treatment, impotency, sex and people with disabilities, and so forth - all issues to which sex and marriage therapists or counsellors would normally pay attention. As such, Craig believes that Wiid and her husband are practicing a form of emotional manipulation (cf. Swart-Walters 2010b:18-19).

\section{Analysis of Wiid's biblical hermeneutics}

As noted above, Wiid has no official training in Christian ministry or biblical interpretation (hermeneutics) and bases her analysis of the Bible on the guidance of the Holy Spirit and hearsay (unfounded information from unidentified sources). By implication, anybody who dares to differ with or criticise her and her views does not possess the Spirit of God: they are acting in the spirit of Satan, who wants to oppose the truth. She says clearly: 'Satan is going to say to me: Where did you hear that?' - implying that Satan and, by implication, people who question her are doubters requiring proof. When Wiid (2009c) is attacked by the media or people, the Lord cries, she claims. It seems that one of her greatest supporters is someone named Kobus de Klerk (2009). He describes the people who criticise Wiid as ungodly, atheists, untruthful, haters of God, 'galbrakers' who hold a grudge against her personally, such as the Pharisees against Jesus.

4. Here Wiid suggests a double meaning: order in the sense of both hierarchy and as the antonym of disorder or chaos.
De Klerk identified himself and Wiid with the Lord (Jesus) by drawing some parallels between the way people flee from him, Wiid and Jesus. On the other hand, according to him, people who support Wiid are true Christians.

Following in the tradition of lay preachers, Wiid refers randomly to biblical verses from the Old and New Testament to support her views and arguments. She has complained that people open their Bibles randomly or draw a 'koringkorrel' ['grain of wheat'] from the box to get a word for the day or to solve problems. But she does the same in the way she quotes from the Bible to support her views (cf. also Buchan et al. 2006:68-69). It was also difficult to follow the line of her argumentation because her conference address was not structured.

Wiid claims to have derived her approach to social issues from 'oom [uncle] Angus', who says: 'We should not be PC (politically correct) but BC (biblically correct)!' (Wiid 2009c). On occasion, her views on important social issues are actually frightening and are proof in and of themselves that she is neither equipped nor qualified to address public audiences concerning these issues. A few examples of her statements include the following:

- She recalled an encounter with a Muslim man 'with a dress on' in a fabric shop and her explanation to her young daughter about Muslims. She says that she does not know who Allah or Muhammad is, but all she knows is that this Allah cannot save anybody if he is not a child of the Lord (Jesus). She called the Muslim man 'kulula' because she could not pronounce or remember his name. Her comment on the issue of Islam is 'God does not tolerate everyone' meaning that God will not tolerate the Muslims or other faiths (Wiid 2009c).

- Her views on homosexuality also reflect her ignorance. During the conference she referred very briefly to homosexuals by saying that although she loves them, their orientation is not according to the Bible and is therefore sinful. But in her book for boys she explains why some people are homosexual. Her motivation for her viewpoint is 'because she believes' that they are not born that way, but are actually boys who are not loved by their fathers and therefore have developed feelings of hate towards men; therefore they do not want to be part of the boys' 'in-group'. They then become lonely and look for the support of other outsider boys, finding consolation with them. Boys can also get confused when they tackle each other in, for example, rugby and touch each other or bath together! (Wiid 2009a:73-74). Girls are sexually confused when they kiss each other and then can become lesbians (Wiid 2009b:21-22).

- She blames women for men's fantasies and unfaithfulness: 'liberated women' do not know how to dress, showing their breasts by wearing tops with low-cut necklines. Girls in mini-skirts and wives whose children are their priority are also to be blamed (Wiid 2009c).

- Wiid seems to blame 'traditions and rules' for the ungodly condition of Christians. She says that Christians should stop taking their parents' traditions as a guideline, namely 
living according to traditions and fixed rules: 'God says that tradition is the only way to nullify the power and word of God' (cf. Mt 15:6). She then quotes Buchan to confirm her statement: 'Oom Angus says "It is not good people who are going to heaven - it is believers!"' (Wiid 2009c).

- She is also of the opinion that unmarried couples who live together are living in sin. They are not living according to the truth of the Word of God (referring to Rm 8:15 probably verse 13!). Her explanation is: 'God created sex as a package deal of body, soul and spirit. Therefore sex is an act of covenant between the married couple and God. Thus, all sex outside of marriage, referring to pornography, masturbation, sms and Internet affairs, engaged couples or widowers who are having sex indicate, with their behaviour, that God is not part of their sexual act anymore. When husband and wife become one, it is not primarily a bodily unification, but rather spiritual. God never meant sex to be physical, but spiritual, and therefore it is a covenant with him. If we choose to have sex outside this marriage covenant then we have chosen to be without God [cf. 1 Cor 6:13-14; it should instead be vv.16-17] and then you are back in hell' (Wiid 2009c).

- Some other areas she points out where Christians compromise their beliefs is to watch programmes such as Liewe Heksie and The Oprah Winfrey Show ('she is not even redeemed' says Wiid) - and to keep crystal fairy ornaments in the house. Here her scripture reference of James 1:22 does not make sense. Wiid says: 'We are living in the end times; the Bible is not words but spirit; we are at war; therefore we have to put on the armour'. My conclusion is that she views these everyday issues as an attack from Satan, who uses these 'innocent things' to corrupt and therefore Christians are inviting him into their lives by bringing these things into their homes (cf. Wiid 2009c).

With all of this in mind, the million-dollar question is therefore: how, according to Wiid, should women interpret the issue of being subservient to men? The first step in her explanation is to acknowledge that the instruction for wives to submit to their husbands comes from the Lord (as presumably reflected in 1 Cor 11:3 and Eph 5:22). Therefore, the order or hierarchy comes from God and not from human beings. According to Wiid (2009c), this does not mean that 'the husband is the boss - only dogs have a boss. Women are not less valued than a man'. Wiid thinks it takes a dynamic and strong woman to be part of the order or hierarchy of God. The implication of this statement is that women who do not submit to this order are weak and to be blamed if they are abused. Therefore, the main purpose of Wiid's ideology is to construct power. She is creating a power inequality within the group 'women', (cf. Nadar \& Potgieter 2010:145-146).

Firstly, according to Wiid (2009c), one should apply these order or hierarchical instructions in the New Testament (cf. 1 Cor 11:2-16; Eph 5:22-33; 1 Pt 3:1-7) only to married couples. And, most importantly, apply them only to married men who are in a covenant relation with God. Therefore, this specific order or hierarchy begins with God and not with the husband. Secondly, Wiid takes her motivation from Genesis 17 to explain why the man's genitals have been chosen to bear the sign of the covenant and not another body part. Wiid (2009c) says that a 'man's penis is the symbol of his pride or glory. Therefore he is circumcised on his penis in order to stand with no pride before God' (!). Implicating that a circumcised man is deformed and defiled. As if traditional circumcised men of Africa or the Middle East are not proud of their penises! She also says that the man or husband becomes like Jesus when he says (to the 'wife', namely the Church): 'I love you'. Wiid is probably making the connection between Jesus, who was humiliated before God on the cross (cf. Phlp $2: 8)$, and the man who is humiliated by his circumcised (deformed) penis! Therefore, he can say in the true spirit of Christ that he loves his wife as Christ has loved the church. She continues:

Jesus' authority has harmed nobody. If you have a husband like that, who doesn't want to be submissive? This is the function or the role that God has given to the wife: to be submissive.

(Wiid 2009c)

Thirdly, another of Wiid's motivations can be found in the creation stories of Genesis 1-2. Wiid (2009c) explains as follows:

God created Adam first according to his own image and Eve secondly. If a man or husband walks with God in paradise, then women are safe. God has 'dreamt' about everything and everyone - therefore, why did he not make them equal? Satan wanted God's kingship but could not get it and was thrown out of heaven. Then, he wanted Adam's kingship. ${ }^{5}$ Therefore, God created for Adam a helper suitable for him (cf. Gn 2:18).

(Wiid 2009c)

Wiid heard from an unidentified person that the Hebrew word for 'helper' actually means armour or shield: ${ }^{6}$

Therefore, wives should fight for their husband's kingship as stated in 1 Corinthians 11 . Wives are becoming a godly reflection, the helper and protector in the same way God was the warrior and protector of Israel. Therefore, in the same way, wives become the warriors, the shields of their husbands and their marriages.

(Widd 2009c)

What is really disturbing about these metaphors is the extensive use of war and therefore violent terminology as part of her ideology, something South Africans could do without - especially concerning violent relationships within the household, as well as in the broader society.

Therefore, according to Wiid:

When God says to the husband: 'You are the king of the house', the husband assumingly does not know what it entails. God then positioned or appointed women to constitute their husband's kingship. Therefore, wives are not subservient to men but to God.

(Widd 2009d)

5.1 did not know Adam was a king! Of whom, if he was the one and only human being at that time?

6.According to Koehler's (1953:696) explanations of the Hebrew word l]zêr in Genesis 2:18, this verse can be translated and interpreted as follows - And the Lord God said: It is not good for the man (i.e. Adam) to be alone; I will make for him a support or help equal and adequate to himself or a support opposite to him (in terms of a or help equal and adequate to himself or a support opposite to him (in terms of a
counterpart). Therefore, there is no indication that the word for 'helper' has the meaning of a 'shield' or 'armour'. 
Wiid then urges women to anoint their husbands with oil (to be placed on their shoes, belt and chest) and especially on those body parts or clothes representing problems in the marriage (such as his underwear, if he has an extra-marital affair that includes pornography and masturbation) (Wiid 2009d). Buchan also exercises the same practice when he 'anoints people with oil as a symbol of the Holy Spirit, and asks for the power of God's healing ...' (Buchan et al. 2006:89).

Furthermore, Wiid's seminars echo heteropatriarchal views which hold that the man or husband is not only the king but also the priest and prophet of the household. Nowhere in the Old or New Testament is the man or husband, or his role, defined as king, priest and prophet. Indeed, not even Jesus officially occupied any of these offices. But because he was seen by the early Christians as the messiah, namely the 'anointed one', the other offices of priest and prophet were also attributed to him because these offices were anointed in Israel. These views of the man or husband as king, priest and prophet are not biblically founded but based on the idea of the man or husband as the head of the wife and household, just as Christ is the head of the Church (1 Cor 11:3; Eph 5:23). I will not go into any further detail on this subject as feminist critics have already problematised the divine status of men extensively (cf. Johnson 1998:431; Wainwright 1991:31).

Nevertheless, what is most disconcerting about Wiid's 'men are kings' ideas and propaganda is that she is telling little boys that they are little kings and will become the kings of their wives one day. She is also encouraging fathers to raise 'godly men'! (Wiid 2009b:36) To me, it is irresponsible to sow these ideas in the minds of young children who do not have the knowledge and skills to understand the implications, particularly in the context of the violent society and world in which we live. Wiid's motivation for her view is that kingship is not for every man but only for those who are in a covenant relation with God. She refers to Genesis 17 for the biblical verification of her arguments. Yet, verse 12 says that 'every male' in Israel shall be circumcised:

For the generations to come every male among you who is eight days old must be circumcised, including those born in your household or bought with money from a foreigner - those who are not your offspring.

Therefore, every male in Israel, whether they observed the Torah or not, was part of the covenant with God. And every Christian man who is baptised will perceive himself as included in the covenant with God, whether he acts or believes according to Jesus' example or not. And this is exactly what we see daily: so-called Christian men, or even clergy, physically and emotionally abusing women and children. For, to be the king means to be in control and to have all the power in hand.

As a result of her opinion that the husband is the king of the wife, Wiid encourages women to submit in full - to give over their sexuality, their bodies and their sexual decisions completely into the hands of their husbands. Wiid says herself that the tongue is powerful and can light an untamed fire (cf. Ja 3:5-10). A recent case that made headline news serves as an example of a man's manipulation of a woman and her body (cf. Swart-Walters 2010a:8-11): Césanne Visser, also known as 'Advokaat Barbie', grew up in a religious house and was a model student who passed all her examinations with distinction. She was rather a shy girl and did not engage in relationships with men until after she had finished her studies. According to her mother, it seems that she was also a virgin when she met a fellow advocate Dirk Prinsloo. Within a month her whole attitude and nature had changed. Firstly, on Prinsloo's demand, Visser enlarged her breasts and lips and followed this with other body shaping, as well as tattoos. According to her mother, the power Prinsloo had over Visser extended to explicit sexual control that involved forcing Visser to have oral sex with him whilst he was driving and whilst her mother was sitting on the back seat. He also physically abused her. What is even more horrifying is that they were also involved in child abuse, for which Visser was imprisoned. It seems that Visser only put an end to the destructive relationship when Prinsloo encouraged her to assist him in engaging in a sexual relationship with her mother as well.

Although I have no idea of the circumstances of Prinsloo's childhood, we do know that Visser grew up in a religious and decent house. The question then becomes: why did a very decent, highly intelligent young woman allow a man to manipulate her to this extent? Indeed, why do the people from the same religious culture who support male supremacy, and Wiid's notion that 'men are kings, godly kings', judge and condemn Visser if they are creating a context where women are instructed from the Bible to submit completely to their husbands - to hand over their sexuality, their bodies and their sexual decisions into the hands of men? Wiid's counter-argument to this example, and thus her answer to these questions, will be that her message is only applicable to married couples and those who are in covenant with God. However, Wiid can give absolutely no guarantee that men who hear her message will not interpret it the way they want and within a context they see fit. She says herself that God has an unbelievable plan of kingship for 'every boy and man' (Wiid 2009b:36). Yet, why should a woman be encouraged to stay in an abusive (un)godly relationship, as Wiid suggests? To crown men as 'godly kings' in a heteropatriarchal society gives them unlimited freedom to exercise their power, as can be seen from Tiger Woods' own admission that he thought that he was entitled to have all of those extra-marital affairs (cf. Whitfield 2010:120-121).

\section{Wiid's demonstration of Formenism}

It is in the context of heteropatriarchy, and its affiliated concepts of masculinism, formenism, heterocentricity, heterosensibilities and the heterosexual imaginary (cf. Nielsen, Walden \& Kunkel 2000:284), that we have to decide whether to restore the masculinism that Wiid and Buchan suggest or rather promote masculinity, as Nadar (2009a:549559) suggests. 
Masculinism stresses the natural and inherent superiority of men and is used to justify the oppression and subjugation of women. It is the antithesis of feminism. There are three ways of maintaining this masculine power over women: brutal force (physical violence), relational and positional power (e.g. belief systems) and discourses of power (everyday language which maintains male dominance over women) (cf. Whitehead \& Barrett 2001:17). Formenism is sustained by women for, or on behalf of, men and, as with masculinism, it subscribes to the inherent superiority of men over women (cf. Nadar \& Potgieter 2010:141ff.) Masculinity, on the other hand, opposes masculinism and formenism and helps to deconstruct male power. It is a study of understanding the ways in which male power is created and maintained. It also assists feminist studies to overcome patriarchy and its maintenance of masculine power over women (cf. Nadar 2009b:2-3). Indeed, regarding Nadar's (2009b:2) remark about 'the mystery of how a man is made', Wiid provides us with a recipe by telling young boys that they are godly men and kings and thereby promoting patriarchal violence and 'muscular' power in its broadest sense (cf. Whitehead \& Barrett 2001:16,400). This is the initiation into a group that is hierarchically more superior in every sense of the word than the other groups, for example women and children - the ideology and restoration of masculinity (Nadar 2009b:2).

Nadar (2009b:5) argues that violence against women is seen mainly as the exercise of power in terms of physical violence or brute force and that positional and discursive power has been ignored or even denied. This illustrates what was said above, namely that positional and discursive power exercised is not perceived by men as violence and is therefore seen by men as permissible and by women as tolerable. A good example of the power men have and what could happen if a woman does not submit, is the instigation of fear. A farmer's wife told me that her patriarchal husband had never lifted a finger against her but she still feared that he would kill her if she disobeys or challenges him, or even goes against his will. How does it happen that this woman still fears her husband even if he does not physically abuse her? Simply, this occurs through discursive power and by demonstrating brutal violence against animals. When men physically abuse women, they often blame the woman for the violence, because she did not submit and obey, or because she was being unfaithful to him. Therefore, the man is exonerated of blame (cf. People Opposing Women Abuse 2010:15).

I further support Nadar's suggestions of alternative models for positive masculinities, namely a deconstruction of masculinity rather than a reconstruction of masculinism. This should be an intellectual as well as a popular task. Here Nadar (2009b) argues that:

If serious academic reflection on masculinity is not "translated" for men who are searching for positive masculinities, then Angus Buchan's mighty men will continue to flourish, at the expense of wo/men.

(Nadar 2009b:9)

(The very recent 'Mighty Men' Conference and Wiid's 'Worthy Women' Conference are prime examples of such flourishing.) Combating this form of masculinity should also involve reconstructing and transforming values of partnership, as opposed to ideologies of headship or hierarchy. In regards to Nadar's suggestion of Jesus as being a positive role model for men today, I am not so sure. I am not convinced that Jesus did enough for the transformation of ideologies of hierarchy into partnership to serve as role model in today's world. Unfortunately, we need more than that - for fundamentalists such as Buchan and Wiid also use Jesus as a model to enforce their ideologies.

\section{Conclusion}

I have suggested elsewhere that the metaphors in the early Christian literature that played a decisive role in establishing the public and private relationship between the early Christian community and the Roman authorities, as well as the relationship between the community and Christ, should be problematised. One example is the metaphor of the slave or slavery, which actually instituted the early Christian theology of obedience and subordination on the one hand and hierarchy and authority on the other hand (cf. Rm 13:4-6; Eph 6:1-9; Col 3:22-4:1; 1 Tm 6:1-2; 1 Pt 2:13-18). Another is the metaphor of the head and the body to illustrate the hierarchical functioning of the family, as well as the Christian community (cf. 1 Cor 11:2-16; Eph 5:21-33; and 1 Pt 3:1-7). The husband is portrayed as the head of the wife, children and slaves, just as Christ is the undisputed head of the Church and universe (cf. Nortjé-Meyer 2005:732-734). These comparisons are based on patriarchal ideology and generate hierarchical authority and power, infused by fundamentalist discourse such as that of Wiid and Buchan.

Another suggestion is that the South African Afrikaans community should also be cognisant of the restructuring of the European society after the Second World War, when the social situation in Germany, France and the Netherlands changed to such an extent that hierarchy and power relations were ideologically and practically undermined (cf. Bessel 1981; Marwick 1974). During periods of great transition in history and changes in ideas about power (e.g. the loss of power, power vacuums, and shifts and change of power) questions are raised concerning the direction societies influenced by these changes should take. Furthermore, Bracher (1995:66) is of the opinion that the concept of power 'often goes hand in hand with concepts such as rule, force, coercion, superiority, leadership, influence, and authority, in social relationships and also in human dealings with nature.' As a result, the reconstruction of a society will include the change of power relations on all levels of interaction. Unfortunately, this issue is too complicated to discuss within the context of this article and so only a few remarks concerning the practical actions that were taken at a school level to introduce a complete change in society are mentioned here.

However difficult it is to discover a common approach to practical issues of common reconstruction, it is possible to identify certain general trends, for example, in Germany (cf. Samuel \& Thomas 1998:167). An area high on the priority list 
was the introduction of new school curricula ${ }^{7}$ that focused on the transformation of class instruction to avoid militarism and the creation of the dutiful, subservient and blindly obedient citizen (cf. Samuel \& Thomas 1998:171). A few practical examples include the following:

- School uniforms or sport activities during school time were not allowed in order to discourage the formation of an exclusive group identity.

- Honouring of war heroism was not tolerated (there is more appreciation in South Africa for the German Second World War heroes than in Germany itself).

- Children were not allowed to call adults 'uncle' or 'aunt' - this is reserved for real relatives only - to reduce the hierarchy and power relations between adults and children and to prevent children from being manipulated by adults.

- Children were also encouraged to see animals as having greater equality with humans by not referring to the body parts of an animal differently to those of a human, for example a paw or beak as opposed to a human's hand or mouth (cf. Bracher 1995:66).

I am of the opinion that it is this kind of complete reconstruction of our society that we need. And, moreover, this has also to come from the men in our society, from male voices raised against an ideology of supremacy - they need to be positive role models, but not in the dangerous form advocated by Gretha Wiid and Angus Buchan.

\section{Acknowledgements Competing interests}

The author declares that they have no financial or personal relationship(s) which may have inappropriately influenced them in writing this paper.

\section{References}

Bessel, R., 1981, Social change and political development in Weimar Germany, Croom Helm, London.

Bracher, K.D., 1995, Turning point in modern times. Essays on German and European history, transl. T. Dunlap, Harvard University Press, Cambridge, MA.

Buchan, A., Greenough, J. \& Waldeck, V., 2006, Faith like potatoes. A story of a farmer who risked everything for God, Monarch Books, Oxford.

Bushell, M.S., Tan, M.D. \& Weaver, G.L., 2005, BibleWorks LLC 1992-2005, compute software, BibleWorks, Norfolk, VA.

Craig, E. \& Stander, H., 2009, Die A tot Z van seks. 'n Seksuele verhouding met jou huweliksmaat soos God dit bedoel het [The A to Z of sex. A sexual relationship with your marriage partner as God meant it to be], Carpe Diem Media, Vanderbijlpark.

De Klerk, K., Gretha Wiid - II. 31 July 2009, viewed 24 March 2010, from http:// www.litnet.co.za/cgi-bin///giga.cgi?cmd=cause_dir_news_item\&cause id=1270\&news_id=70867\&cat_id $=160$

Dunne, G.A. 2003, 'A Passion for "Sameness"? Sexuality and gender accountability', in F. Weeks, J. Holland, \& M. Waites, Sexualities and society. A reader, pp. 57-68, Polity Press, Cambridge.

Gibbons, M., Limoges, C., Nowotny, H., Schwartzman, S., Scott, P. \& Trow, M., 1994 The new production of knowledge. The dynamics of science and research in contemporary societies, Sage, London.

Hawthorne, S., 2007, 'Heteropatriarchy: Globalisation, the institution of heterosexuality and lesbians', paper presented at the International Feminist Summit, Townsville, Australia, 17-20 July.

7.The system varies throughout Germany because each state decided on its own educational policies (cf. Weiler 1996).
Jackson, N., 2009, Women get their own 'Mighty Men', viewed 24 March 2010 from http://www.news24.com/SouthAfrica/News/Women-get-own-MightyMen-20090716

Jackson, S., 2003, 'Heterosexuality, heteronormativity and gender hierarchy: Some reflections on recent debates', in F. Weeks, J. Holland, \& M. Waites, Sexualities and society. A reader, pp. 69-83, Polity Press, Cambridge.

Johnson, E.E., 1998, 'Ephesians', in C.A. Newsom \& S.H. Ringe (eds.), Women's Bible commentary, pp. 428-432, expanded edn., Westminster John Knox Press, Louisville, KY.

Koehler, L. \& Baumgartner, W., 1953, 'Lexicon in Veteris Testamenti libros: Wörterbuch zum hebräischen Alten Testament in deutscher und englischer Sprache [A dictionary of the Hebrew Old Testament in English and German], Brill, Leiden.

Marwick, A., 1974, War and social change in the twentieth century, a comparative study of Britain, France, Germany, Russia and the United States, Macmillan, London.Mikaelsson, L. 2008, 'Gendering the history of religions', in P. Antes, A.W. Geertz \& R.R. Warne (eds.), New approaches to the study of Religion, 1. Regional, critical, and historical approaches, Walter de Gruyter, Berlin.

Nadar, S., 2009a, 'Palatable patriarchy and violence against Wo/men in South Africa - Angus Buchan's Mighty Men's Conference as a case study of masculinism', Scriptura 102(3), 549-559.

Nadar, S., 2009b, Who's afraid of the Mighty Men's conference?, viewed 24 March 2010, from http://www.iam.org.za/index.php?option=com_content\&task=view\& id=256\& Itemid=99

Nadar, S. \& Potgieter, C., 2010, 'Liberated through submission? The Worthy Woman's Conference as a case study of formenism', Journal of Feminist Studies in Religion 26(2), 141-151. http://dx.doi.org/10.2979/FSR.2010.26.2.141

Nielsen J.M., Walden, G. \& Kunkel, C.A., 2000, 'Gendered heteronormativity: Empirical illustrations in everyday life', The Sociological Quarterly 41(2), 283-296. http:// dx.doi.org/10.1111/j.1533-8525.2000.tb00096.x

Nortjé-Meyer, L., 2005, 'Questioning the perfect male body: A critical reading of Ephesians 4:13', Scriptura 3, 731-739.

Nortjé-Meyer, L., 2010, 'Deconstructing the heteronormative image of the early Christian household: Reconsidering gender as a key organising concept of family functioning', Acta Patristica et Byzantina 21(2), 141-151.

People's Global Action Conference, 2008, 'Gendered heteropatriarchy and introduction text for the gender issues', proceedings of the 5th People's Global Action Gathering, Athens, Greece, 20-27 August, viewed 16 April 2010, from http://indy.gr/library/gendered-heteropatriarchy

People Opposing Women Abuse, 2010, Criminal injustice: Violence against women in South Africa. Shadow report on Beijing +15, March 2010, prepared by POWA with the AIDS Legal Network, on behalf of the One in Nine Campaign and the Coalition for African Lesbians, viewed 16 April 2011, from http://www2.ohchr.org/english/ bodies/cedaw/docs/ngos/POWA_Others_SouthAfrica48.pdf

Samuel, R.H. \& Thomas, R.H., 1998, Education and society in modern Germany, Routledge, London.

Schüssler-Fiorenza, E., 2001, Wisdom ways: Introducing feminist biblical interpretation, Orbis Books, New York.

Starbuck, W.H., 2006, The production of knowledge: The challenge of social science research, Oxford University Press, Oxford.

Swart-Walters, L., 2010a, 'Verwoes deur ' $\mathrm{n}$ monster [Destroyed by a monster]', Huisgenoot, 04 March, pp. 8-11.

Swart-Walters, L., 2010b, 'Seksreëls: Nee, O Sonde!' [Sex rules: Oh no!]', Huisgenoot, 04 March, pp. 18-19.

Viljoen, S. \& Koenig-Visagie, L.H., 2011, 'Gender representation in Christian book covers: A case study', Verbum et Ecclesia 32(1), Art. \#487, 9 pages. doi:10.4102/ ve.v32i1.487

Wainwright, E.M., 1991, Towards a feminist critical reading of the Gospel according to Matthew, Walter de Gruyter, Berlin. http://dx.doi.org/10.1515/9783110877106

Weiler, H.N., 1996, Educational change and social transformation: Teachers, schools and universities in Eastern Germany, Falmer Press, London.

Whitehead, S.M. \& Barrett, F.J. (eds.), 2001, The masculinities reader, Polity Press, Cambridge.

Whitfield, N., 2010, 'Die berouvolle akteur [The penitential actor]', Huisgenoot, 04 March, pp. 120-121.

Wiid, G., 2009a, Seks slim vir ouers en tieners. Verstaan jou tiener se lewe, lus en lyf [Sex wise for parents and teenagers. Understand your teenager's life, lust and body], Carpe Diem Media, Vanderbijlpark.

Wiid, G., 2009b, Lyfslim vir seuns. Alles waaroor seuns wonder ... oor seks, meisies en die dinge daaronder [Body wise for boys. Very thing boys marvel about ... sex, girls and the things down there], Carpe Diem Media, Vanderbijlpark.

Wiid, G., 2009c, DVD, Worthy women conference, Maranatha Christian Publishing, Brits Productions, Centurion.

Wiid, G., 2009d, DVD, Seks in die huwelik-Jou lus, las of liefde? [Marital sex-Your lust, burden or love?], Maranatha Christian Publishing, Brits Productions, Centurion.

Wiid, G., 2009e, DVD, Verstaan jou man beter: Finessekenner [Understand your husband better: Finesse expert], Carpe Diem Media, Vanderbijlpark. 